поняття не тотожні, тому завдання людства через розвиток і розквіт національних культур привести нашу цивілізацію до Культури, тобто до «культу Світу» (як перекладається це слово).

\title{
Література:
}

1. Бердяев Н. А. О назначении человека. Москва. 2010. 478 с.

2. Блаватская Е. П. Из пещер и дебрей Индостана. Москва. 2007. $832 \mathrm{c}$.

3. Блаватская Е. П. Разоблаченная Изида. Москва, Санкт-Петербург. 2007. 1360 с.

4. Вернадский В. И. Биосфера и ноосфера. Москва, 1989. 261 с.

5. Крэнстон С. Е. П. Блаватская. Рига. 1999. 736 с.

6. Рерих Е. И. Письма. / 1919-1933. Москва. 2011. Т.1. 496 с.

7. Рерих Е. И. Листы дневника. / 1924-1925. Москва. 2011. T. 2. $400 \mathrm{c}$.

8. Фромм Э. Иметь или быть? Москва. 2004. 384 с.

9. Blavatsky H. P. Civilization, the death of art and beauty. Lucifer. 1891. № 45. P. 177-186. URL: https://theosophy.world/ (дата звернення: 19.11.21)

\section{DOI https://doi.org/10.30525/978-9934-26-178-7-26}

\section{ВВЕДЕННЯ ДО ПРОБЛЕМАТИКИ КОСТЮМНОГО ЕНВАЙРОНМЕНТУ ТА ЙОГО ГУМАНІСТИЧНІ ЦІННОСТІ}

\author{
Токар М. I. \\ кандидат мистецтвознавства, доцент, \\ доцент кафедри аудіовізуального мистецтва, перший проректор \\ з науково-педагогічної роботи \\ Харківська державна академія дизайну і мистеитв \\ м. Харків, Украӥна
}

Тематика екології та вторинної переробки матеріалів 3 метою подальшого їхнього використання залишається досить актуальною в сучасному мистецтві. Створені таким чином арт-об'єкти вирізняються 3-поміж інших, особливо такі, що мають подвійну адресацію, а саме спрямовані безпосередньо на глядача та на його середовище задля зміни останнього. Такі зразки сучасного мистецтва дістали на сьогодні назву «енвайронмент». 
Власне ж енвайронмент, на думку М. Константина та Д. Ларсена, має три підвиди, зокрема архітектурний, костюмний та експериментальний [5, с. 36]. Саме «костюмний енвайронмент», що $є$ поняттям сучасного текстильного мистецтва, виокремлюється всебічним впливом на глядача (людину).

При цьому важливим $є$ визначення своєрідності саме «костюмного енвайронменту», оскільки екстравагантні форми одягу, що на разі існують у моді, також можуть бути об'єктами мистецтва, але не $\epsilon$ «костюмним середовищем».

До грунтовного розгляду поняття «костюмного енвайронменту» («костюмного середовища») вдається Н. Н. Цветкова у праці «Мистецтво ручного ткацтва», розглядаючи цей термін як такий, у межах якого можна передбачати, що костюм розглядається не як об'єкт сучасної моди, а як об'єкт сучасного мистецтва, який може бути одягнений на людину, а власне арт-об'єкт, що виконаний в одному екземплярі, має певну концепцію. Науковець зазначає при цьому, що хоч такий об'єкт і можна одягати на людину, але переважно його не можна використовувати як одяг, оскільки його використання має іншу настанову $[4$, с. 60$]$.

У свою чергу «костюмний енвайронмент» має такі основні умовно названі типи: нетрадиційний, екологічний, конструктивний, єднальний, декоративний, незалежний [4, с. 60].

Такий умовний розподіл базується на тому, зокрема, який матеріал було застосовано для виготовлення об'єкту. Таким чином, нетрадиційний виготовлений не з текстильних матеріалів (дерево, метал, папір, пластикові відходи тощо) і пов'язаний із вторинною переробкою матеріалів.

Використання в костюмі елементів, що спрямовані на збереження навколишнього середовища, є відмінністю екологічного «костюмного енвайронменту», при цьому естетичні завдання вирішуються переважно через створений художній образ костюму, що втілюють образи існуючих чи фантазійних істот чи природних явищ.

Арт-об'єкти ускладненої конструкції, що зовні мають вигляд одягу, але через свою складність не можуть бути використані таким чином, дістали назву конструктивного «костюмного енвайронменту», а людина, що одягає такий костюм, потрапляє в «полон» до нього і вже не може бути самостійною особистістю, перетворюючись на певний інструмент, стаючи частиною задуму художника і виявляючи його ідеї, закладені при створенні такого арт-об'єкту. [4, с. 62].

Єднальний тип «костюмного енвайронменту» передбачений виявлятися через поєднання в одне ціле певними елементами створеного костюму із залучення декількох людей. 
Найпоширенішим можна назвати декоративний «костюмний енвайронмент», особливість якого полягає в зображенні частин тіла та внутрішніх органів, у намаганні передати художником бачення наскрізь людського тіла, що втрачає при цьому власну таїну. При цьому типі відбувається певне нарощування компонентів в уявному ланцюгу сприйнятті одягненої людини (людини в оболонці), що зазвичай логічно виглядає як одяг-тіло, а завдяки декоративному типові починає сприйматися як тіло-одяг-тіло.

Останнім є незалежний тип «костюмного енвайронменту», що не передбачає участі людини, оскільки арт-об'єкти, незважаючи на те, що мають форму одягу, насправді ним не $\epsilon$, а експонування відбувається в просторі чи на стіні. Подекуди такі об'єкти створено з не текстильних матеріалів, як наприклад, з алюмінію, розрізаних світлин тощо.

Відтак, розглянувши поняття «костюмного енвайронменту» та запропоновані на сьогодні науковцями його основні типи [4, с. 60], можна дійти висновку, що особливість впливу костюмного енвайронменту, незважаючи на типи, полягає в тому, що його адресатом є як зовнішнє середовище, так і внутрішнє середовище людини, iї внутрішній світ, що зазнають певних змін під враженням від створених арт-об'єктів. Водночас художник вбачає в глядачеві не тільки реципієнта, а й подекуди його залучає до створення певного образу та втілення власного художнього задуму, пропагуючи таким чином гуманістичні цінності.

Отже, як власне, на думку О.М. Лагоди, «мода і мистецтво - це два автономні світи» [3, с. 26], так припускаємо, що і костюмний енвайронмент $\epsilon$ окремою цариною актуального мистецтва, що й становитиме в подальшому окремий напрямок досліджень.

\section{Література:}

1. Заблоцька С. До проблеми співвідношення образу та художнього образу костюма. Вісник ЛАМ. Львів, 1998. Вип. 9. C. $177-181$.

2. Затулий А. И. Костюм в социокультурном контексте авангарда и культуры: дис. ... канд. культуролог. наук: 17.00.01. К.-на-А., 2003. $208 \mathrm{c}$.

3. Лагода О.М. Мода і мистецтво: взаємодія в контексті репрезентацій. Вісник Харківської державної академії дизайну $i$ мистеитв, 2014. С. 20-26.

4. Цветкова Н.Н. Искусство ручного ткачества. С-Пб., 2014. 270 с.

5. Constantin M., Larsen J. Beyond Craft: The Art Fabric. New York, 1972. $294 \mathrm{p}$. 